\title{
Eksotisk importsykdom og svøpe for fattigfolk
}

\author{
Kala-azar er en eksotisk importsykdom i Norge. På det indiske subkontinent er sykdommen en svøpe for \\ fattigfolk. Med et epidemiologisk bakteppe preget av ernæringsproblemer og akutte infeksjoner stilles \\ diagnosen ofte sent. Dette skjer både fordi en snikende sykdomsdebut fører til at alternative, tradisjonelle \\ behandlingsmetoder fors $\varnothing$ kes først, og fordi det kliniske bildet med anemi, stor utspilt abdomen, vekslende \\ febrilia og dermatitt ofte ses ved underernæring med interkurrente infeksjoner.
}

Publisert først på nett 29.3. 2012

Kala-azar er den viscerale formen for leishmaniasis. I Norge er sykdommen svært sjelden, og her er leukemi den mest nærliggende differensialdiagnosen. Nordøst i India derimot, er sykdommen relativt vanlig. I Nepal ses den oftest hos dem som bor langs de store elvene som skjærer seg så dypt ned i fjellene at klimaet langs elvebredden blir tropisk. Jeg gir i denne kommentaren noen utfyllende opplysninger om sykdommen, og illustrere dette med en kasuistikk.

\section{Kala-azar ved Okhaldunga sykehus}

Ved Okhaldhunga sykehus i Nepals utkantstrøk ble en to år gammel gutt innlagt. Han ble båret av faren fra der de bor nede ved en stor elv, et par dagsmarsjer fra sykehuset. Han hadde vært slapp og hatt dårlig appetitt $\mathrm{i}$ tre måneder, noe hoste og vekslende feber. De siste to ukene var han blitt verre, tiltakende slapp, blek og hadde økende ødemer.
Ved gjentatte besøk hos en lokal sjaman var de blitt fortalt at sykdommen skyldtes at de hadde unnlatt å blidgjøre fedrenes ånder med et årlig ritual. De måtte derfor ofre først en høne, så en gris. Da det var gjort og gutten fremdeles ikke ble bedre, fikk de beskjed om å ofre en svart geit. Det hadde de ikke råd til, så de gikk til den lokale helseposten. Her fikk gutten amoksicillin og paracetamol, fremdeles uten effekt. Først da oppsøkte de sykehuset.

Ved innkomst veide han $9,1 \mathrm{~kg}$, var trist, blek og hadde generelle ødemer. Han hadde hepatosplenomegali, en rumpert abcess i høyre lyske og petekkier i venstre lyske og på venstre bein (fig 1). Blodprøver tatt ved sykehusets enkle laboratorium viste: $\mathrm{Hb} 5,3 \mathrm{~g} / 100 \mathrm{ml}(10,5-14,0 \mathrm{~g} / 100 \mathrm{ml})$, hvite blodceller $5,8 \cdot 10^{9} / 1\left(6-15 \cdot 10^{9} / 1\right)$ hvorav $46 \%(40-80 \%)$ nøytrofile, blodplater $26 \cdot 10^{9} / 1\left(150-450 \cdot 10^{9} / 1\right)$. SR $<20$. Kreatinin $35 \mu \mathrm{mol} / 1(27-62 \mu \mathrm{mol} / \mathrm{l})$. K 39

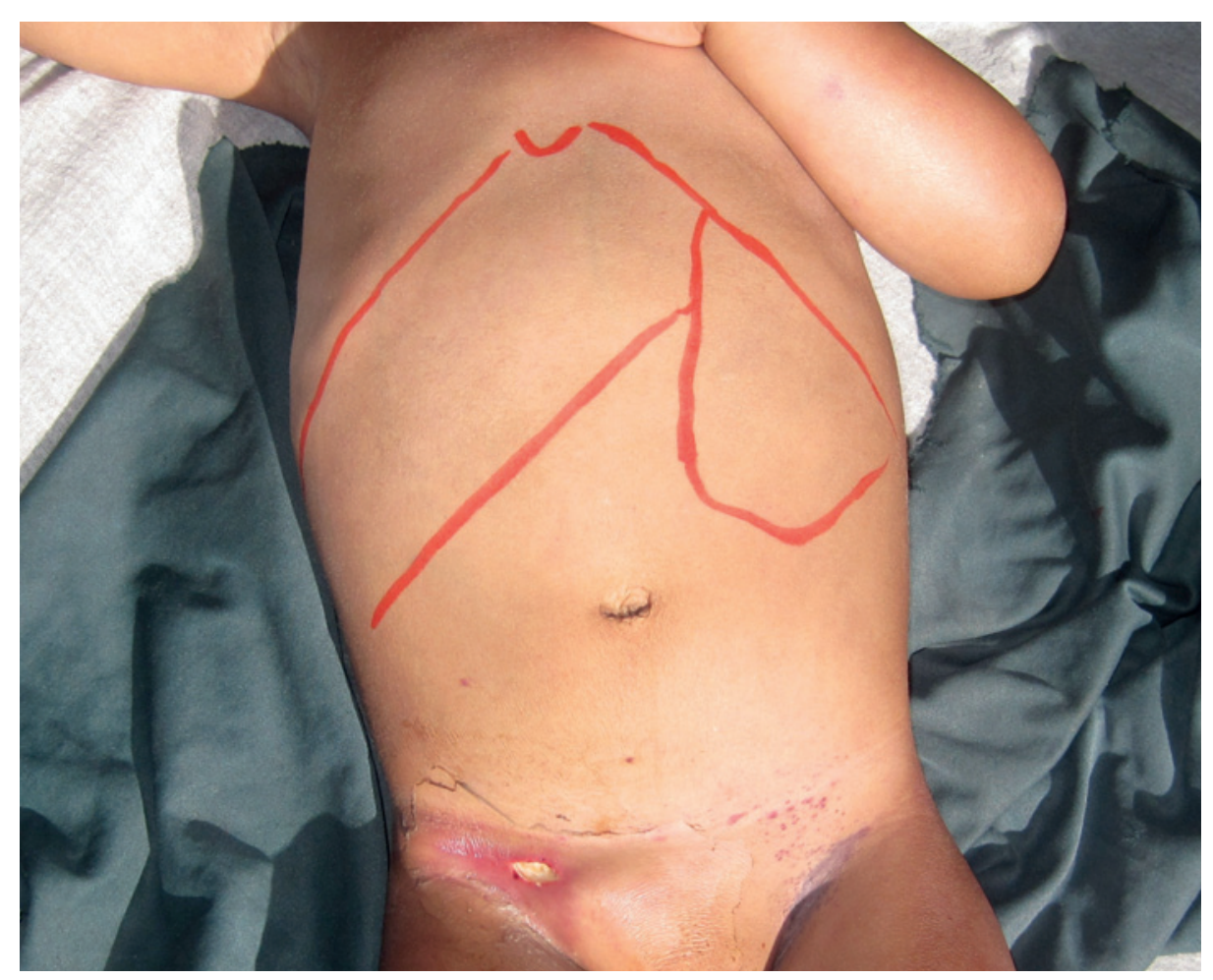

Figur 1 Bilde tatt dagen etter innkomst, og etter blodtransfusjon. Her har han bedre farge og mindre ødemer enn ved innkomst. Størrelse av lever og milt er markert. Det ses petekkier i venstre lyske og spontanrumpert abcess i høyre lyske. Foto Erik Bøhler (en serologisk test på antistoffer mot Leishmania donovani) positiv. Prøvesvarene bekreftet vår kliniske mistanke om sykdommen kala-azar.

\section{Behandling}

Pasienten fikk blodtransfusjon så snart prøvesvar forelå, for miltefosin gir vi ikke til svært anemiske pasienter. Blodtransfusjon her er ikke enkelt, sykehuset har ingen blodbank. Vanligvis brukes pasientenes pårørende som blodgivere, men verken farens eller onkelens blod var kompatibelt. Da må sykehusets egen stab fungere som donorer.

Så ble det startet med miltefosin oralt, $2,5 \mathrm{mg} / \mathrm{kg} \times 1$, som ble gitt i 28 dager. Pasientene er ofte anorektiske i startfasen og han fikk en melkebasert ernæringsblanding $(« F 75 »)$ som han greide å ta. Videre fikk han, som rutine hos alle svært underernærte barn, antibiotika, albendazol mot innvollsorm, vitamin A, et multivitaminpreparat og tilskudd av kalium, mineraler og sporstoffer.

\section{Kommentarer til sykehistorien}

Dette var et ganske typisk tilfelle av kalaazar, med unntak av at vår pasient hadde lave verdier for hemoglobin og blodplater, men nesten normale for hvite blodceller. Nesten normal konsentrasjon av hvite blodceller er så uvanlig at man kan mistenke målefeil. Så godt som alle slike pasienter vi har sett her tidligere har hatt betydelig reduserte verdier i alle tre blodcellerekker. Blekhet og petekkier avspeiler dette. Abcess, og spontanruptur av denne, avspeiler immunsuppresjon og underernæring. Det er påfallende at vår pasient hadde en SR på bare 3. De fleste pasientene med kala-azar vi har sett her i Okhaldhunga, har hatt tresifret SR, mens noen, som denne gutten, faktisk har hatt normale verdier. Laboratorietesten «K 39» er nyttig, og den har nå en overkommelig pris også i den fattige verden.

\section{Generelt om kala-azar}

Kala-azar ble nylig omtalt i en artikkel i Tidsskriftet (1). Som nevnt der betyr navnet «svart feber». Det er en anglifisering fra hindi, og henspiller på at noen pasienter med sykdommen får gråaktig hyperpig- 
mentert, tørr hud. Vår pasient hadde ikke det, det er ikke vanlig hos småbarn. I nevnte artikkel gis en gjennomgang av sykdommen, med hovedvekt på hematologiske aspekter. Ettersom pasienten der var smittet i Spania, og det indiske subkontinent har over $60 \%$ av verdens tilfeller (2), nevnes her noen faktorer spesifikt for denne delen av verden.

Her skyldes sykdommen parasitter av arten Leishmania donovani, som overføres ved bitt av sandfluen Phlebotomus argentipes. I motsetning til parasitten som finnes rundt Middelhavet, i Amerika og andre steder (overveiende Leishmania infantum), gir den indiske varianten bare sykdom hos menneske, og kan affisere både barn og unge voksne (2). En studie i Nepal fant følgende disponerende faktorer: hus med sprekker i gulv og vegger (der sandfluene som sprer sykdommen holder til), soveplass direkte på bakken, overfylte bolighus og lav inntekt (3). Så dette er typisk en sykdom som rammer de fattigste.

Inntil ganske nylig ble kala-azar i Nepal behandlet med natriumstibuglukonat parenteralt (4), en pentavalent arsenikkforbindelse som har vært kjent i 50 år. Det kan imidlertid ha alvorlige bivirkninger (5), og man har sett økende resistens (6). Liposomalt amfotericin $\mathrm{B}$, som brukes i rike land, er så dyrt at det ikke er noe alternativ. Det har ikke vært utviklet nye, gode medisiner mot sykdommen før helt nylig. Ingen tjener penger på å forske frem nye medisiner mot sykdommer hos fattigfolk.

Men for få år siden spilte indiske leger en vesentlig rolle i utviklingen av det perorale midlet miltefosin, et fosfolipid. Miltefosin er nå førstehåndsmidlet mot kala-azar i alle fall i Nepal, India og Bangladesh, og har vært et vesentlig fremskritt i bekjempelse av sykdommen. Stoffet ble opprinnelig utviklet som et kreftmiddel, og er teratogent (7).

For å oppnå kontroll med denne sykdommen, som er dødelig uten behandling og årlig affiserer 500000 nye pasienter, må forebyggende tiltak vektlegges. Vaksine finnes foreløpig ikke. Bruk av impregnerte myggnett har vist seg atskillig mindre effektivt enn det er mot malaria, antakelig fordi sandfluer oftest biter på dagtid. Innendørs spraying av bolighus med insektmiddel har derimot vist seg effektivt (8).

Visceral leishmaniasis er en sykdom med mange aspekter, fra avansert hematologi i Norge til primærhelse, medisinsk antropologi og folkehelse i Nepal.

Pasientens far har gitt samtykke til at artikkelen blir publisert.

\section{Erik Bøhler}

bohler@wlink.com.np

Medical Coordinator

Okhaldhunga Community Hospital

Nepal

Erik Bøhler (f. 1954) er dr.med. og spesialist i barnesykdommer. Han har arbeidet i Bhutan fra 1983 til 1992, deretter tilknyttet Barnesenteret ved Ullevål universitetssykehus frem til 2002. Han har siden da arbeidet i Nepal, er Medical Coordinator ved Okhaldhunga Sykehus. Forfatter har fylt ut ICMJE-skjemaet og oppgir ingen interessekonflikter.
Litteratur

1. Skram MK, Bjerring S, Hermansen NO et al. En femten måneder gammel jente med feber og pancytopeni. Tidsskr Nor Legeforen 2011; 131: 2482-6.

2. Palatnik-de-Sousa C, Day MJ. One Health: the global challenge of epidemic and epidemic leishmaniasis. Paracit Vectors 2011; 4: 197 www. paracitesandvectors.com/content/4/1/197 (12.3.2012).

3. Shah H. Prevalence of visceral leishmaniasis associated with the behaviors of the people in rural areas. JNMA J Nepal Med Assoc 2005; 44 116-20.

4. Karki P, Koirala S, Parija SC et al. A thirty day course of sodium stibogluconate for treatment of Kala-azar in Nepal. Southeast Asian J Trop Med Public Health 1998; 29: 154-8.

5. Sundar S, Sinha PR, Agrawal NK et al. A cluster of cases of severe cardiotoxicity among kala-azar patients treated with a high-osmolarity lot of sodium antimony gluconate. Am J Trop Med Hyg 1998; 59: 139-43.

6. Thakur CP, Sinha GP, Pandey AK et al. Do the diminishing efficacy and increasing toxicity of sodium stibogluconate in the treatment of visceral leishmaniasis in Bihar, India, justify its continued use as a first-line drug? An observational study of 80 cases. Ann Trop Med Parasitol 1998: 92: 561-9.

7. Kala Azar WHO. Training module. New Delhi: Publishing and Sales, WHO. India, 2008.

8. Stauch A, Sarkar RR, Picado et al. Visceral leishmaniasis in the Indian Subcontinent: Modelling epidemiology and control. PLoS Negl Trop Dis 2011: 5: e1405

Mottatt 16.1. 2012, første revisjon innsendt 18.2. 2012, godkjent 23.2. 2012. Medisinsk redaktør Merete Kile Holtermann. 